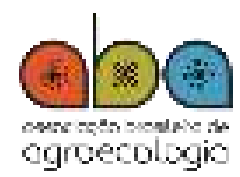

ISSN: $1980-9735$

\title{
PESQUISA-AÇÃO E VISIBILIZAÇÃO DO SUJEITO: MULHER E RAÇA
}

Vívian Delfino Motta ${ }^{1}$

Joan Scott, em seu livro Cultura e Trabalho (1998), aponta que visibilizar as práticas também visibiliza os sujeitos. Nesse sentido, a pesquisa avançou ao olhar para as práticas como espaço fundamental para a construção do conhecimento agroecológico. Segundo Scott, é preciso enfatizar que visibilizar as práticas não elucida os processos de opressão. A agenda da pesquisa-ação sobre das mulheres, mas sem mostrar como o machismo as oprime, não esclarece, tampouco, o contraponto antimachista. Da mesma forma, pesquisar os conhecimentos ancestrais das comunidades tradicionais, desprezando o racismo e o genocídio negro e indígena não constrói uma Agroecologia antirracista.

A sociedade utiliza processos de visibilidade e invisibilidade das categorias que compõem o tecido social. A visibilidade garante recursos e oportunidades que, em um cenário caótico como o que estamos vivendo, possibilita às pessoas visíveis grandes chances de sobreviverem, conservando, parcialmente ou totalmente, seus recursos para a reprodução social. No nosso país, as pessoas brancas, ricas e com acesso ao poder conseguem se esgueirar das calamidades através do uso do dinheiro, das leis e do capital político. Já as pessoas que não possuem tais características: a população negra, pobre, LGBTQI+, (em que, muitas vezes, uma só pessoa possui em si todas essas condições) constituem o que Achille Mbembe (2018) denomina de corpos matáveis. O trabalho das camadas mais baixas da população é fundamental para manutenção do sistema capitalista, mas é preciso mantê-las em um número controlável e sem que a submissão às classes dominantes seja questionada. No entanto, se o sistema produz pobres, o mesmo sistema precisa eliminar parte desses pobres. No Brasil, a existência dessas pessoas obriga o governo a destinar recursos para serviços públicos, ação que um governo desumano como o atual, não deseja realizar. Os protestos nos EUA pela morte de George Floyd, também agitaram o movimento negro brasileiro, causando apreensão nas camadas mais privilegiadas quanto de manifestações.

As pesquisas no universo da Agroecologia pecam quando não desvelam aspectos de gênero e raça, pois, em muitos de nós e de nossos conhecimentos, somos os corpos matáveis, somos sobreviventes diários da necropolítica! A Agroecologia deve colaborar com a destruição dos estereótipos que criminalizam as pessoas e as fixam nos espaços de marginalidade, precisa ser um espaço de enunciação com sujeitos e "sujeitas" falantes, precisa elucidar os processos de invisibilidade que dão a falsa sensação de ausência das(os) marginalizadas(os).

1 Professora do Instituto Federal de São Paulo. Coordenadora do GT Mulheres da Associação Brasileira de Agroecologia-ABA. E-mail: vivianmotta@ifsp.edu.br
O jornal Folha de São Paulo (14/06/2020) destaca que no Brasil, 43.389 pessoas entram para as estatísticas como vítimas fatais da COVID -19. Ao mesmo tempo, as estruturas de mortes já estabelecidas auxiliam o vírus a impactar de forma brutal a vida das pessoas mais pobres do país, o editorial publicado na revista inglesa 
The Lancet (09/05/2020) aponta que cerca de 13,5 milhões de brasileiros vivem em favelas, sem ou com acesso limitado à água limpa e ao saneamento básico, condições essenciais para a evitar a contaminação pelo novo coronavírus.

Doença, pobreza e racismo se misturam, escancarando formas antigas e "inovadoras" de inserção da necropolítica em nosso cotidiano. O Jornal Folha de São Paulo (07/04/2020) evidencia o medo que pessoas negras tem de usarem as máscaras feitas em casa e serem confundidas com criminosos, aumentando as chances de serem vítima da violência policial. Ao mesmo tempo, o governo negligencia as necessidades da população, pensando apenas na manutenção do poder a partir de processos inaceitáveis para um país que se identifica como democrático. Nesse cenário, podemos nos perguntar como a Agroecologia se posiciona frente aos fatos?

A Agroecologia, diferente de outras ciências, nos permite transformar, rever, propor novos paradigmas que construam conhecimentos para uma sociedade mais justa e solidária. Felicidade, afeto, companheirismo, não são apenas palavras soltas, mas são princípios para que o bem-viver se materialize no campo e na cidade. O compromisso já foi firmado, nos Congressos Brasileiros de Agroecologia e nos Encontros Nacionais de Agroecologia, que não torna possível voltarmos atrás, é preciso que nossas pesquisas possam estudar elementos de gênero e raça que deflagrem ações de ruptura com o machismo e o racismo. 